Effecti veness of two novel ani oni $c$ and cat i oni $c$ pl at i num compl exes i $n$ the treat ment of ost eosar coma

\begin{tabular}{|l|l|}
\hline 著者 & 五十嵐 健太郎 \\
\hline 著者別表示 & I gar ashi Kent ar o \\
\hline $\begin{array}{l}\text { jour nal or } \\
\text { publ i cat i on t i t l e }\end{array}$ & 博士論文本文Ful I \\
\hline 学位授与番号 & 13301甲第4275号 \\
\hline 学位名 & 博士 (医学 $)$ \\
\hline 学位授与年月日 & 2015- 06-30 \\
\hline URL & $\mathrm{ht} \mathrm{t} \mathrm{p:} \mathrm{//hdl} \mathrm{.} \mathrm{handl} \mathrm{e.} \mathrm{net} \mathrm{/2297/45877}$ \\
\hline
\end{tabular}




\title{
Effectiveness of Two Novel Anionic and Cationic Platinum Complexes in the Treatment of Osteosarcoma
}

\author{
Kentaro Igarashi ${ }^{1}$, Norio Yamamoto ${ }^{1}$, Katsuhiro Hayashi ${ }^{1}$, Akihiko Takeuchi ${ }^{1}$, Shinji Miwa ${ }^{1}$, Akira Odani ${ }^{2}$ \\ and Hiroyuki Tsuchiya ${ }^{1, *}$
}

${ }^{I}$ Department of Orthopaedic Surgery; ${ }^{2}$ Division of Pharmaceutical Sciences, Kanazawa University, Kanazawa, Japan

\begin{abstract}
Aim: This study aimed to characterize the cellular basis of the platinum cytotoxicity of two novel platinum complexes, $3 \mathrm{Pt}$ and $1 \mathrm{Pt}$, in comparison with that of cisplatin. $3 \mathrm{Pt}$ comprises anionic phosphate moieties, while $1 \mathrm{Pt}$ comprises neutral aromatic ligands.
\end{abstract}

Methods: We compared the cytotoxic potency of $3 \mathrm{Pt}$ and $1 \mathrm{Pt}$ with that of cisplatin in osteosarcoma cell lines and an orthotopic mouse model.

Results: The cytotoxic potency of 3Pt was markedly higher than that of cisplatin in all cell lines. Both novel platinum complexes showed a complete lack of cross resistance in cisplatin-resistant cells. Caffeine enhanced the cytotoxic

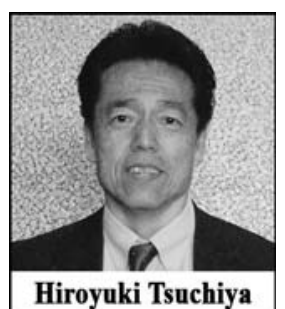
potency of these novel platinum complexes, as observed for cisplatin. Apoptosis after drug administration was observed by DNA ladder formation and an annexin V/PI assay. DNA double-strand breaks were confirmed by phosphorylation of histone H2AX. In vivo, the antitumor activity of $3 \mathrm{Pt}$ and $1 \mathrm{Pt}$ was superior and similar, respectively, to that of cisplatin. Both novel platinum complexes exerted strong antitumor effects on osteosarcoma in vitro and in vivo.

Conclusions: 3Pt may be an effective drug for the treatment of bone cancer because the PO3 moiety has a high affinity to bone, as exhibited by bisphosphonates, and is expected to decrease the incidence of side effects at extraskeletal sites and overcome drug resistance. Cationic 1Pt may also be an effective antitumor drug because of its unique chemical structure and properties. Further investigations to detail the antitumor effects of these ionic Pt complexes on osteosarcoma are warranted.

Keywords: Antitumor, bone-targeting platinum, cisplatin resistance, DNA interaction, osteosarcoma, platinum complex, proteasome inhibitory platinum.

\section{BACKGROUND}

For nearly 30 years, cisplatin has been one of the most effective antitumor agents available for the treatment of solid human tumors, including osteosarcoma [1]. However, some tumors are intrinsically resistant to cisplatin, and the development of resistance presents a major clinical barrier to effective treatment [2]. The efficacy of cisplatin is also limited by side effects such as dose-dependent renal toxicity and hematotoxicity.

Osteosarcoma is a common malignant primary bone tumor that develops in patients aged 10-25 years, and its prognosis has improved significantly with advances in chemotherapy and local surgical control [3]. Since 1989, our research group has published reports on caffeine-potentiated chemotherapy. Caffeine, a trimethylsubstituted xanthine, enhances the damage to cellular DNA and may inhibit the post-replication repair of sublethally damaged DNA [4]. Although the 5-year survival rate for nonmetastatic osteosarcoma in our department has improved to $90 \%$ with caffeine-potentiated chemotherapy [5-7], the prognoses of recurrent and metastatic osteosarcoma remain poor, with a long-term survival rate of $>20 \%$ [8-11].

Recently, we designed several platinum-based chemotherapy agents using new concepts [12]. Ionic platinum complexes were prepared to increase solubility and avoid platinum nephrotoxicity. Bisphosphonates, metabolically stable pyrophosphate analogs, are known for their bone-targeting properties and are used as therapeutic agents for bone diseases such as osteoporosis and bone

*Address correspondence to this author at the Department of Orthopedic Surgery, Kanazawa University, 13-1 Takaramachi, Kanazawa 920-8641, Japan; Tel: +81-76-265-2374; Fax: +81-76-234-4261;

E-mail: tsuchi@med.kanazawa-u.ac.jp metastasis [13, 14]. Bisphosphonates have a strong affinity for calcium and show strong inhibition to osteoclastic resorption [15]. Therefore, we incorporated bisphosphonates into a platinum complex to target bone tissue.

Another design was based on the structure of the cisplatinDNA(-G-G-)-HMG (high mobility group) protein adduct [16], where aromatic ring stacking played an important role in adduct formation. The formed adduct is a key to escape attack by the DNA repair enzyme complex. Among the new protein targets, the proteasome may be a major target of $1 \mathrm{Pt}$ because of its strong inhibitory capabilities [12]. The proteasome is involved in the regulation of nuclear factor kappa-light-chain-enhancer of activated B cells (NF-kappa B) activity and drives several anti-apoptotic activities and oncogenic factor expression [17].

\section{OBJECTIVES}

In this study, we analyzed the antitumor effects of two novel platinum complexes, 3Pt and 1Pt (Fig. 1) [12], on osteosarcoma and compared their efficacy with that of cisplatin both in vitro and in vivo.

\section{MATERIALS AND METHODS}

\section{Ethics Statement}

The animal study was conducted in accordance with the Guidelines on the Care and Use of Laboratory Animals issued by Kanazawa University. The protocol was approved by the ethical committee of Kanazawa University (permit number: AP-112171). All surgeries were performed under sodium pentobarbital anesthesia. All efforts were made to minimize animal suffering, to decrease the number of animals used, and to utilize possible alternatives to in vivo techniques. 


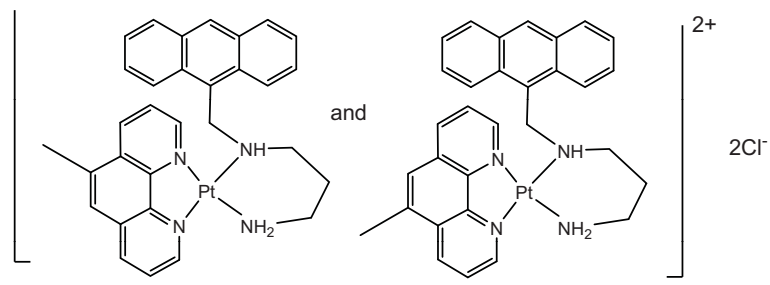

$1 \mathrm{Pt}$

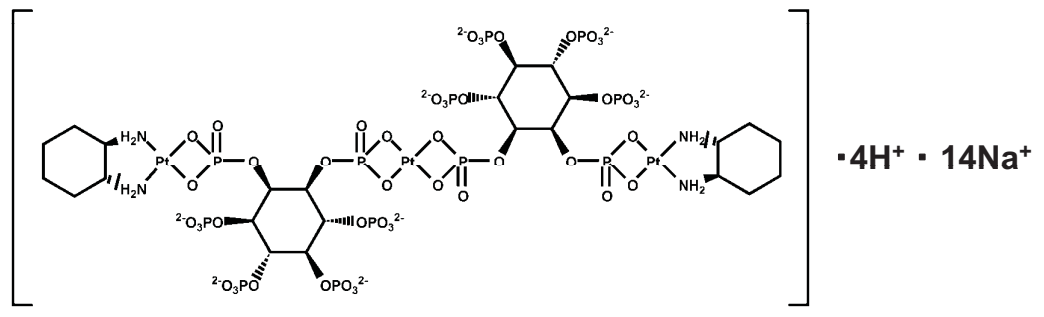

$3 \mathrm{Pt}$

Fig. (1). Structures of the novel platinum compound 1Pt and 3Pt.

\section{DRUGS}

Both novel platinum drugs were synthesized by Professor Odani at the Division of Pharmaceutical Sciences, Kanazawa University, Kanazawa, Japan.

\section{Pt ([Pt(5-methyl-1,10-phenanthroline)(N-(9-anthracenylmethyl)- trimethylenediamine(AtC3))] C12 Synthesis}

For 1Pt synthesis, $0.42 \mathrm{~g}(1.3 \mathrm{mM}) \mathrm{N}$-(9-anthracenylmethyl)trimethylenediamine (AtC3) $2 \mathrm{HCl}, 0.16 \mathrm{~g}(1.5 \mathrm{mM}) \mathrm{Na}_{2} \mathrm{CO}_{3}$ in $10 \mathrm{~mL} \mathrm{H}_{2} \mathrm{O}$, and $5 \mathrm{~mL}$ EtOH were added to a suspension of $\mathrm{Pt}(5-$ methyl-1,10-phenanthroline(MP)) $\mathrm{CI}_{2}(0.46 \mathrm{~g}, 1.0 \mathrm{mM})$ in $10 \mathrm{~mL}$ $\mathrm{H}_{2} 0$, and the mixture was stirred for approximately $3 \mathrm{hrs}$ at $80^{\circ} \mathrm{C}$. The black mixture was filtered while still hot to remove undissolved materials. After cooling to room temperature, the filtrate was evaporated till it decreased to $1-2 \mathrm{~mL}$ and acetone was added to the residue. After standing the residue overnight in a refrigerator, a pale yellow precipitate was formed, which was collected on a filter and dried under a vacuum to maintain the structure of the metal complex, which yielded $0.49 \mathrm{~g} \mathrm{(62 \% ).}$

Elemental analysis: $\mathrm{C}_{31} \mathrm{H}_{30} \mathrm{~N}_{4} \mathrm{PtCl}_{2} \cdot 5 \mathrm{H}_{2} \mathrm{O} \cdot 0.5 \mathrm{NaCl}$

Observed: C, 44.14\%; H, 4.30\%; N, 6.26\%

Calculated: C, 43.64\%; H, 4.81\%; N, 6.57\%

Structure confirmations: The structure of $1 \mathrm{Pt}$ was indicated in Fig. 1 by H-NMR of $1 \mathrm{Pt}(\mathrm{Pt}-\mathrm{Mphen}-\mathrm{AtC} 3$ complex) showed 2 signals with same intensity, which indicated two geometric isomers in square planner complex (cis-trans isomers).

\section{H-NMR (D2O)}

$8.85(\mathrm{~d}, 1 \mathrm{H}), 8.75(\mathrm{~d}, 1 \mathrm{H}), 8.66(\mathrm{~m}, 4 \mathrm{H}), 8.36(\mathrm{~d}, 1 \mathrm{H}), 8.28(\mathrm{~d}$, $2 \mathrm{H}), 8.16(\mathrm{~d}, 1 \mathrm{H}), 7.94(\mathrm{~m}, 3 \mathrm{H}), 7.83(\mathrm{t}, 2 \mathrm{H}), 7.70(\mathrm{~m}, 6 \mathrm{H}), 7.62(\mathrm{~s}$, $1 \mathrm{H}), 6.95(\mathrm{~m}, 4 \mathrm{H}), 6.74(\mathrm{~m}, 2 \mathrm{H}), 6.53(\mathrm{~m}, 2 \mathrm{H}), 6.42(\mathrm{~m}, 2 \mathrm{H}), 5.43$ $(\mathrm{d}, 2 \mathrm{H}), 3.62(\mathrm{~m}, 2 \mathrm{H}), 3.44(\mathrm{~m}, 2 \mathrm{H}), 3.28(\mathrm{~m}, 2 \mathrm{H}), 3.03(\mathrm{~m}, 2 \mathrm{H})$, $2.73(\mathrm{~s}, 3 \mathrm{H}), 2.67(\mathrm{~s}, 3 \mathrm{H}), 2.51(\mathrm{~m}, 4 \mathrm{H})$

13C-NMR (D2O)

19.96(1C), 27.05(1C), 45.62(1C), 53.19(1C), 55.93(1C),
124.86(1C), 125.51(1C), 126.57(2C), 127.80(3C), 131.07(3C), $132.12(3 \mathrm{C})$,

138.07(1C), 140.12(1C), 142.20(1C), 144.69(1C), 145.56(1C), 146.49(1C), 147.12(2C), 147.91(1C), 148.23(1C), 149.13(1C), 149.62(1C), 164.99(1C)

\section{Pt ([Pt(Pt(1R,2R-diaminocyclohexane)(myo-inositol-1,2,3,4,5, 6-hexakisphosphate) $)_{2}$ ]) Synthesis}

For 3Pt synthesis, $\mathrm{Ag}\left(\mathrm{NO}_{3}\right)(0.01 \mathrm{~g}, 0.07 \mathrm{mM})$ was dissolved in $1 \mathrm{~mL} \mathrm{H} \mathrm{H}_{2} \mathrm{O}$ and added to $\mathrm{K}_{2} \mathrm{PtCl}_{4}(0.01 \mathrm{~g}, 0.03 \mathrm{mM})$ in $2 \mathrm{~mL}$ $\mathrm{H}_{2} \mathrm{O}$, and the mixture was stirred overnight. $\mathrm{Pt}(\mathrm{Pt}(1 \mathrm{R}, 2 \mathrm{R}-$ diaminocyclohexane(dach)) (myo-inositol-1,2,3,4,5,6-hexakisphosphate (IP6) $) \cdot 10 \mathrm{Na} \cdot 14 \mathrm{H}_{2} \mathrm{O}(0.10 \mathrm{~g}, 0.07 \mathrm{mM})$ in $1 \mathrm{~mL} \mathrm{H}_{2} \mathrm{O}$ was added to the solution and stirred for $2-3$ days at $50{ }^{\circ} \mathrm{C}$. After removal of $\mathrm{AgCl}$ by filtration, the filtrate was evaporated and $\mathrm{MeOH}$ was added to the residue. The off-white powder was collected and dried under a vacuum to maintain the structure of the metal complex, which yielded $0.06 \mathrm{~g} \mathrm{(50 \% )}$.

Elemental analysis: $\mathrm{C}_{16} \mathrm{H}_{78} \mathrm{~N}_{4} \mathrm{O}_{65} \mathrm{P}_{6} \mathrm{Pt}_{3} \mathrm{Na}_{18}\left(\mathrm{Pt}(\mathrm{Pt}(\text { dach }) I \mathrm{P} 6)_{2} \cdot 18\right.$ $\mathrm{Na} \cdot 2 \mathrm{CH}_{3} \mathrm{OH} \cdot 15 \mathrm{H}_{2} \mathrm{O}$ )

Observed: C, 10.90\%; H, 2.75\%; N, 1.96\%

Calculated: C, $11.30 \%$; H, 3.17\%; N, 1.83\%

Structure confirmations: The structure of $3 \mathrm{Pt}$ was indicated in Fig. 1 by P-NMR which showed 6 signals with same intensity and the two P signals at 2 and 3 in IP6 were not shifted by $\mathrm{pH}$ change.

\section{H-NMR (D2O)}

dach: 1.158(t,br,4H), 1.301(s,br, 4H), 1.578(s, br, 4H), 2.056(t, br, $4 \mathrm{H}) .2 .406(\mathrm{~m}, \mathrm{br}, 4 \mathrm{H})$;

IP6: $3.78(\mathrm{~m}, 2 \mathrm{H}), 4.03(\mathrm{~m}, 6 \mathrm{H}), 4.38(\mathrm{~m}, 4 \mathrm{H})$

13C-NMR (D2O):

dach: 26.78(4C), 34.63(4C), 65,77(4C),

IP6: 73.88(1C), 74.52(1C), 76.19(4C), 77.70(2C), 78.55(2C), 79.64(1C), 80.31(1C) 


\section{Cell Lines and Growth Conditions}

The LM8, MG63, and 143B osteosarcoma cell lines were used for the experiments. The murine osteosarcoma cell line LM8 was provided by the RIKEN Tsukuba Institute BioResource Center (Ibaraki, Japan) through the National Bio-Resource Project of the Ministry of Education, Culture, Sports, Science, and Technology of Japan. All other cell lines were obtained from the American Type Culture Collection (Rockville, MD, USA). The osteosarcoma sublines LM8cisR, 143BcisR, and MG63cisR were established by exposing the cisplatin-sensitive osteosarcoma cell lines to successive increments in cisplatin concentrations. Resistance was stable in the absence of the selecting agent for at least 3 months. Cells were maintained in the log phase by supplementation with fresh medium 2-3 times/week. All cells were grown in Roswell Park Memorial Institute 1640 medium supplemented with $10 \%$ fetal bovine serum, $100 \mathrm{U} / \mathrm{mL}$ penicillin, and $100 \mu \mathrm{g} / \mathrm{mL}$ streptomycin.

\section{Growth Inhibition Assay}

Cellular viability was assessed using the 2-(2-methoxy-4nitrophenyl)-3-(4-nitrophenyl)-5-(2,4-disulfophenyl)-2H-tetrazolium (WST-8) dye reduction assay. Briefly, cells were seeded in 96-well flat-bottomed microplates $(100 \mu \mathrm{L} /$ well $)$ at $5 \times 10^{4}$ cells $/ \mathrm{mL}$, incubated for $24 \mathrm{hrs}$ at $37{ }^{\circ} \mathrm{C}$, and exposed to various concentrations of the test compounds for $72 \mathrm{hrs}$. For each concentration, at least eight wells were used. After incubation with the test compounds, $10 \mu \mathrm{L}$ of WST-8 solution was added to each well. The microplates were further incubated for $3 \mathrm{hrs}$ at $37^{\circ} \mathrm{C}$, and absorption was measured using a microprocessor-controlled microplate reader (iMarkTM; Bio-Rad Laboratories, Hercules, CA, USA) at $450 \mathrm{~nm}$. Half maximal inhibitory concentration $\left(\mathrm{IC}_{50}\right)$ values were derived from dose-response curves.

\section{Apoptosis Assay}

DNA fragmentation was analyzed by agarose gel electrophoresis. Osteosarcoma cells were exposed for $48 \mathrm{~h}$ to $12.5 \mu \mathrm{M}$ of each test compound. DNA was extracted using the Apoptotic DNA ladder kit (catalog no.: 11835 264; Roche Applied Science, Indianapolis, IN, USA) according to the manufacturer's instructions. The extracted DNA was electrophoresed on a $1.5 \%$ agarose gel containing $1 \mu \mathrm{g} / \mathrm{mL}$ of ethidium bromide at $100 \mathrm{~V}$. The DNA fragments were visualized by exposing the gel to ultraviolet light and photographed.

Flow cytometric assessment of annexin $\mathrm{V}$ binding to apoptotic cells was determined by assessing phosphatidylserine exposure to annexin V-fluorescein isothiocyanate (FITC) binding using the Annexin V-FITC staining kit (catalog no.: IM3546; Beckman Coulter, Fullerton, CA, USA) according to the manufacturer's instructions. Cells $\left(10^{4}\right)$ were analyzed in a flow cytometer (desk top cell sorter JSAN; Bay Bioscience Co., Ltd., Hyougo, Japan). Annexin $\mathrm{V}$ is used to identify cells in all stages of programmed cell death $[18,19]$. Propidium iodide (PI) exclusively stains cells with disrupted membranes and is used to identify late apoptotic and dead cells.

\section{Gamma-H2AX ( $\gamma$-H2AX) Immunofluorescence Staining}

Cells were grown to $70 \%$ confluence in 4-well Lab-Tec Chamber Slides (Nunc, Naperville, IL, USA) and cultured for $24 \mathrm{hrs}$ in the presence of $10 \mu \mathrm{M}$ of each compound. At each time point, the cells were fixed. The slides were washed and incubated with mouse monoclonal antibodies to histone $\gamma-\mathrm{H} 2 \mathrm{AX}$ (dilution, 1:300; Upstate Biotechnology, Lake Placid, NY, USA), followed by incubation with Alexa Fluor 488-labeled goat antibodies conjugated to mouse immunoglobulin G (dilution, 1:700; Molecular Probes, Eugene, OR, USA). The slides were mounted in fluorescence mounting medium (Dako Cytomation, Hamburg, Germany), and the fluorescent signals were visualized using confocal laser scanning microscopy (BZ-9000; Keyence Corporation, Osaka, Japan). Three random fields, each containing at least 100 cells, were examined at $100 \times$ magnification. Nuclei containing $\geq 10$ immunoreactive foci were counted as $\gamma-\mathrm{H} 2 \mathrm{AX}$-positive, and the percentage of positive cells was determined [20].

\section{ORTHOTOPIC MOUSE MODEL}

\section{Animals}

Female nude mice (BALB/c-nu/nu) aged 4-6 weeks were purchased from Sankyo Laboratory Inc. (Toyama, Japan) and housed in a barrier facility under high-efficiency particulate air filtration. The mice were bred under germ-free and specific pathogen-free conditions. The animal study was conducted in accordance with the Guidelines on the Care and Use of Laboratory Animals issued by Kanazawa University. The protocol was approved by the ethical committee of Kanazawa University (permit number: AP-112171). All surgeries were performed under sodium pentobarbital anesthesia. All efforts were made to minimize animal suffering, to reduce the number of animals used, and to utilize possible alternatives to in vivo techniques.

\section{Intratibial 143B Transplantation}

For intratibial transplantation, cells were suspended in $10 \mu \mathrm{l}$ of PBS containing $5 \mu \mathrm{g}$ of Matrigel ${ }^{\mathrm{TM}}$ Basement Membrane Matrix (Becton Dickinson, Bedford, MA, USA) to prevent the suspension from leaking out. A suspension of $2 \times 10^{5} 143 \mathrm{~B}$ cells was implanted. All mice were checked and weighed daily, and tumors were measured once weekly using digital calipers. Two weeks after transplantation, mice were treated intraperitoneally with cisplatin $(20 \mu \mathrm{M} / \mathrm{kg}), 1 \mathrm{Pt}(20 \mu \mathrm{M} / \mathrm{kg}), 3 \mathrm{Pt}(15 \mu \mathrm{M} / \mathrm{kg})$, or normal saline $(\mathrm{n}=$ 8 each). We administered the compounds 1 day per week. Treatments were repeated weekly for 3 weeks. Six weeks after transplantation, all mice were sacrificed.

\section{Primary Tumor Growth}

Tumor volumes were calculated using the following equation: volume $=4 \pi(\mathrm{A} / 2)(\mathrm{B} / 2)(\mathrm{C} / 2) / 3$, where $\mathrm{A}$ is the width (average distance in the medial-lateral plane), $\mathrm{B}$ is the length (average distance in the proximal-distal plane), and $\mathrm{C}$ is the width (average distance in the anterior-posterior plane).

\section{Statistical Analysis}

Data are presented as means \pm standard deviation and were compared between groups using the unpaired Student's t-test. A Pvalue of $<0.05$ was considered statistically significant.

\section{RESULTS}

\section{Cytotoxicity}

The cytotoxic activity of cisplatin, $1 \mathrm{Pt}$, and $3 \mathrm{Pt}$ was determined in the 143B, MG63, LM8, 143BcisR, MG63cisR, and LM8cisR osteosarcoma cell lines, which were incubated for $72 \mathrm{~h}$ with the platinum-based compounds. Cell survival was evaluated as described in the Materials and Methods section. Each compound significantly inhibited cisplatin-susceptible cell growth in a dosedependent manner (Fig. 2). The IC50 value of 3Pt was significantly lower than that of cisplatin, and the cytotoxic activity of each compound was potentiated by adding $1 \mathrm{mM}$ caffeine (Table 1). Cisplatin resistance was approximately 2.85 -fold, with $\mathrm{IC}_{50}$ values of LM8 and LM8cisR cells. The resistance index (RI) was 2.85 for LM8cisR, 1.83 for 143BcisR, and 4.17 for MG63cisR (Fig. 3, Table 2). 3Pt potency was markedly higher than cisplatin potency in LM8, 143B, and MG63 cells, whereas 1Pt and 3Pt completely 

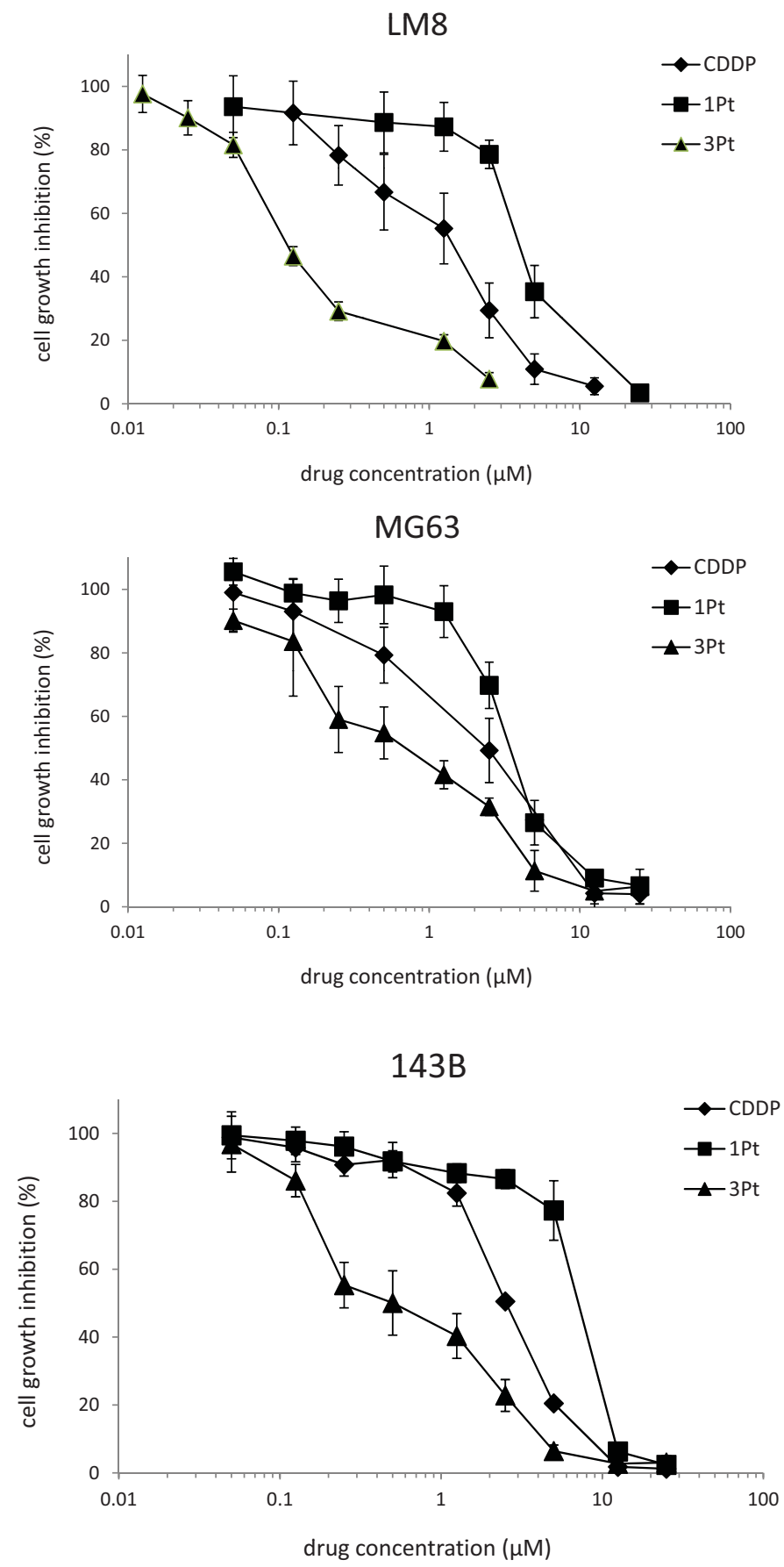

Fig. (2). Growth inhibition assay of each platinum complex against LM8, MG63, and 143B cells Osteosarcoma cells were incubated with cisplatin, 1Pt, or 3Pt for 72 hrs and evaluated using the WST-8 assay.

Table 1. IC $\mathrm{IC}_{50}$ value of cisplatin and 1Pt, 3Pt against LM8, MG63, and 143B cells with and without adding $1 \mathrm{mM}$ of caffeine.

\begin{tabular}{|c|c|c|c|c|c|c|}
\hline & \multicolumn{2}{|c|}{ CDDP IC $_{\mathbf{5 0}}(\boldsymbol{\mu M})$} & \multicolumn{2}{c|}{ 1Pt IC $_{\mathbf{5 0}}(\boldsymbol{\mu M})$} & \multicolumn{2}{c|}{ 3Pt IC $_{\mathbf{5 0}}(\boldsymbol{\mu M})$} \\
\hline & & $+\mathbf{C A F} 1 \mathrm{mM}$ & & + CAF 1 mM & + CAF 1 mM \\
\hline \hline LM8 & $1.09 \pm 0.24$ & $0.47 \pm 0.10^{* *}$ & $3.38 \pm 0.49$ & $1.46 \pm 0.29^{* *}$ & $0.12 \pm 0.01$ & $0.068 \pm 0.015^{* *}$ \\
\hline MG63 & $1.85 \pm 0.48$ & $1.02 \pm 0.09^{* *}$ & $3.40 \pm 0.47$ & $2.32 \pm 0.20^{* *}$ & $0.72 \pm 0.15$ & $0.48 \pm 0.07^{* *}$ \\
\hline 143B & $2.19 \pm 0.15$ & $1.24 \pm 0.10^{* *}$ & $5.83 \pm 0.30$ & $3.31 \pm 0.53^{*}$ & $0.62 \pm 0.07$ & $0.48 \pm 0.08^{* *}$ \\
\hline
\end{tabular}

Osteosarcoma cells were incubated with either platinum complex with and without caffeine for $72 \mathrm{hrs}$ and then assessed via the WST-8 assay. 
Table 2. IC I $_{50}$ value of cisplatin and 1Pt, 3Pt against LM8, MG63, 143B, LM8cisR, MG63cisR, 143BcisR cells.

\begin{tabular}{|c|c|c|c|c|c|c|c|c|c|}
\hline Drug & LM8 IC I $_{50}(\mu \mathrm{M})$ & LM8-cisR IC I0 $_{50}(\mu \mathrm{M})$ & RI & MG63 IC $\mathrm{IO}_{50}(\mu \mathrm{M})$ & MG63-cisR IC I0 $_{50}(\mu \mathrm{M})$ & RI & $143 \mathrm{~B} \mathrm{IC}_{50}(\mu \mathrm{M})$ & $143 \mathrm{~B}-\operatorname{cisR} \mathrm{IC}_{50}(\mu \mathrm{M})$ & RI \\
\hline CDDP & $1.20 \pm 0.06$ & $3.41 \pm 0.10$ & 2.85 & $1.09 \pm 0.06$ & $4.53 \pm 0.21$ & 4.17 & $1.00 \pm 0.03$ & $1.83 \pm 0.10$ & 1.83 \\
\hline $1 \mathrm{Pt}$ & $2.72 \pm 0.18$ & $2.74 \pm 0.13$ & 1.01 & $2.47 \pm 0.12$ & $2.41 \pm 0.11$ & 0.97 & $2.10 \pm 0.05$ & $1.97 \pm 0.10$ & 0.93 \\
\hline $3 \mathrm{Pt}$ & $0.050 \pm 0.006$ & $0.049 \pm 0.004$ & 0.98 & $0.173 \pm 0.014$ & $0.178 \pm 0.021$ & 1.03 & $0.091 \pm 0.007$ & $0.078 \pm 0.007$ & 0.85 \\
\hline
\end{tabular}

$\mathrm{RI}($ resistance index $)=$ cisplatin-resistant/cisplatin-sensitive $\mathrm{IC}_{50}$. Osteosarcoma cells were incubated with cisplatin, $1 \mathrm{Pt}$, or $3 \mathrm{Pt}$ for $72 \mathrm{hrs}$ and assessed by the WST-8 assay.
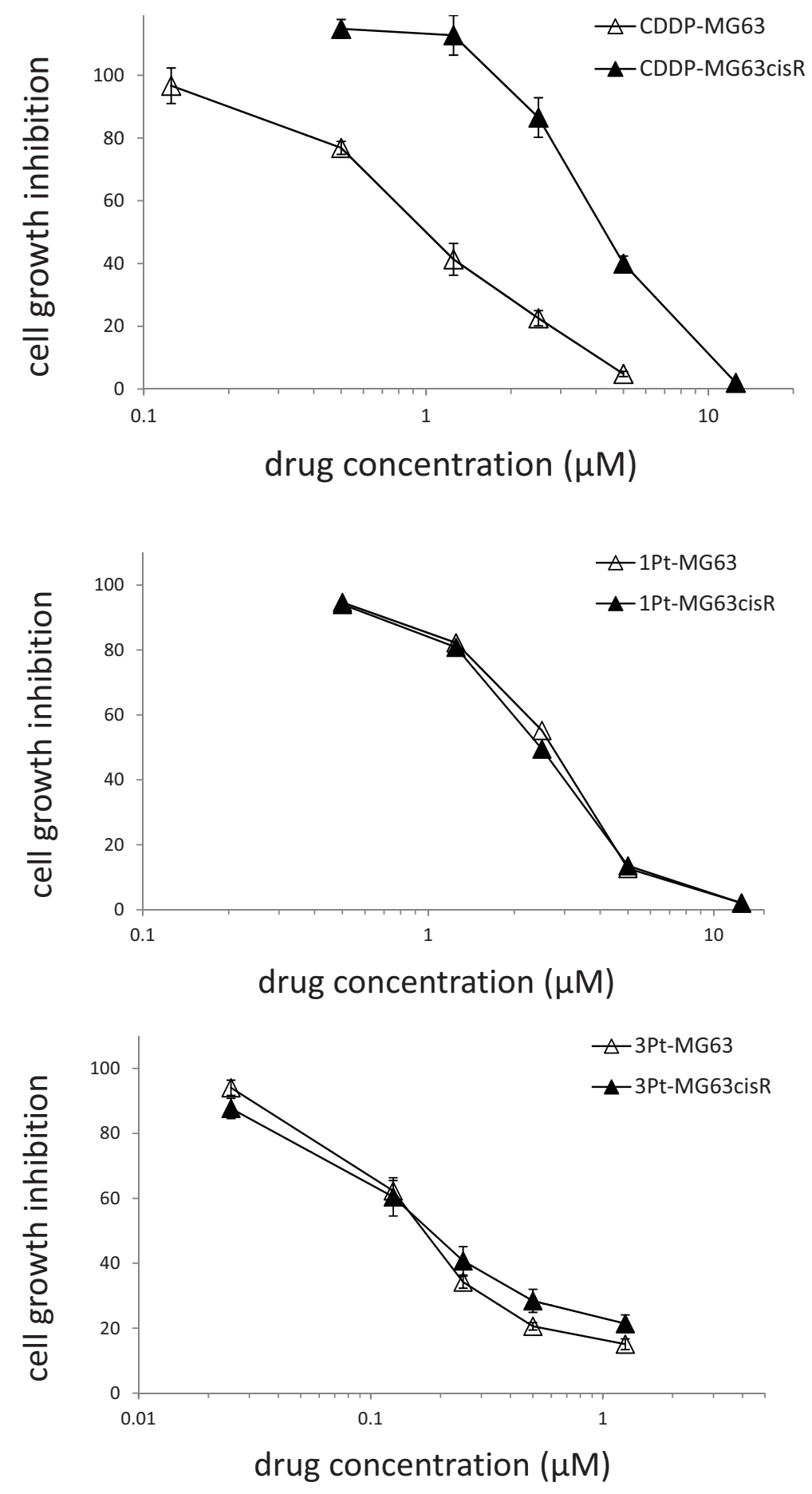

Fig. (3). A growth inhibition assay of each platinum complex against the MG63, MG63cisR cell lines. Osteosarcoma cells were incubated with cisplatin, 1Pt, or $3 \mathrm{Pt}$ for $72 \mathrm{hrs}$ and assessed by the WST- 8 assay. 


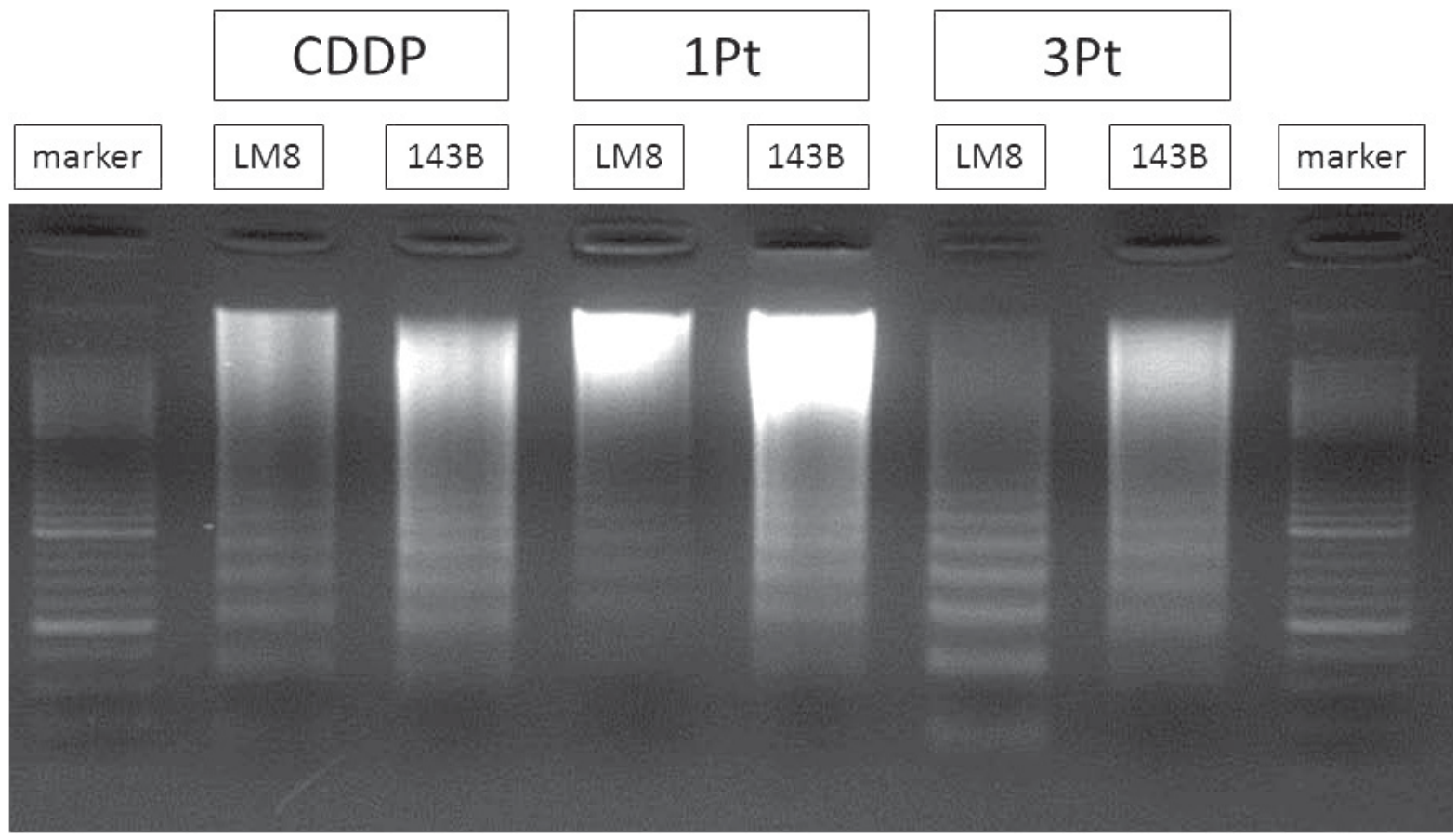

Fig. (4). Agarose gel electrophoresis for analysis of DNA fragmentation induced by the platinum complexes. Osteosarcoma cells were exposed to $12.5 \mu \mathrm{M}$ of each compound for $48 \mathrm{hrs}$. DNA was extracted and electrophoresed in an agarose gel. The DNA fragments were then visualized by exposing the gel to ultraviolet light.

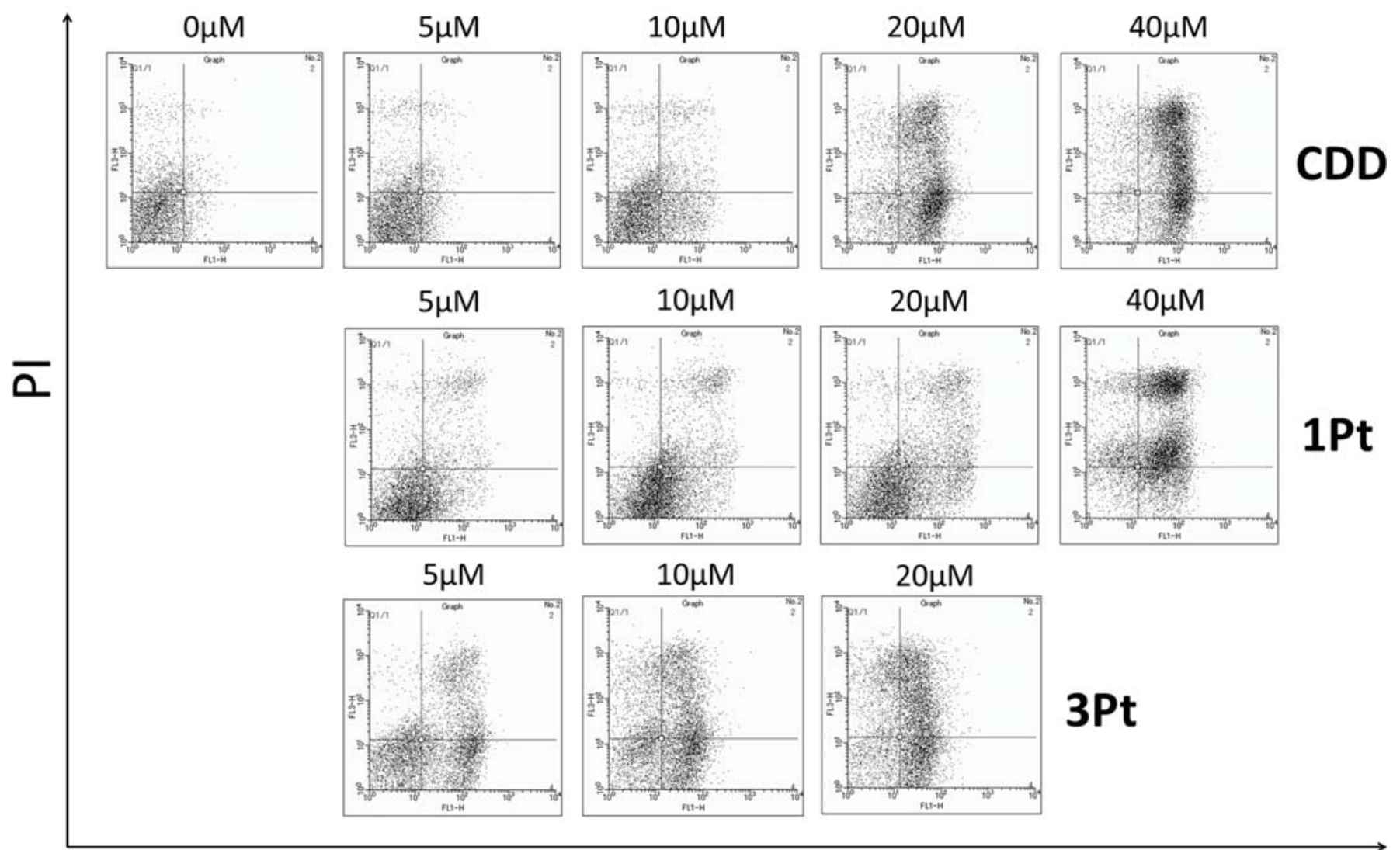

\section{AnnexinV - FITC}

Fig. (5). The annexin V-FITC/PI assay to assess apoptosis of 143B cells induced by the platinum complexes. 143B cells were exposed to each compound for $24 \mathrm{hrs}$, and flow cytometry assay was performed using an annexin V-FITC/PI assay kit. 
lacked cross-resistance in LM8cisR, 143BcisR, and MG63cisR cells.

\section{Apoptosis Induction}

Treatment with each platinum complex for $48 \mathrm{hrs}$ resulted in DNA ladder formation (Fig. 4). After the 24-hrs treatment, cisplatin and $1 \mathrm{Pt}$ demonstrated early apoptosis at a $10 \mu \mathrm{M}$ concentration, whereas 3Pt showed early and late apoptosis at lower concentrations compared with cisplatin (Fig. 5).

\section{$\gamma$-H2AX Immunofluorescence Staining}

The effect of cisplatin is induced through DNA damage [21]. Because the chemical structures of $1 \mathrm{Pt}$ and $3 \mathrm{Pt}$ are quite different from those of cisplatin, we determined whether $1 \mathrm{Pt}$ and $3 \mathrm{Pt}$ induced

A

Control

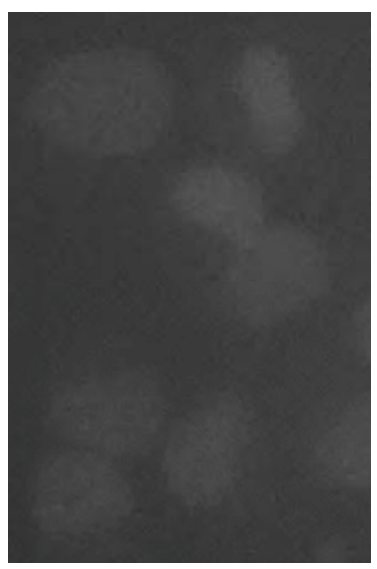

CDDP

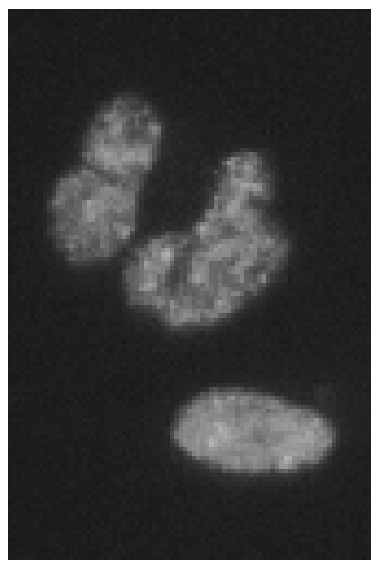

1Pt

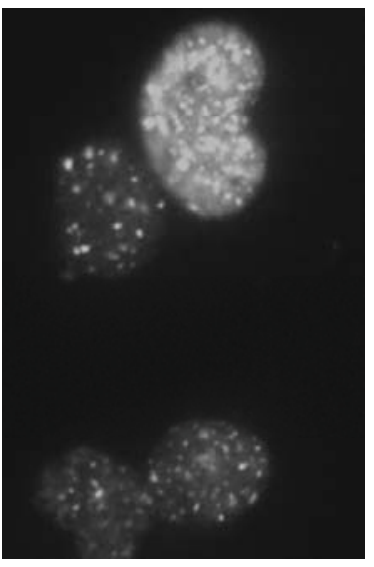

3Pt

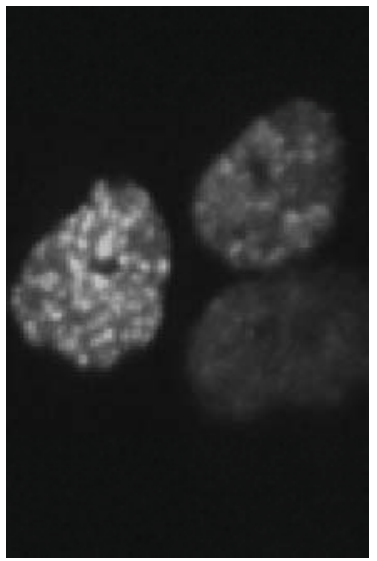

B

LM8
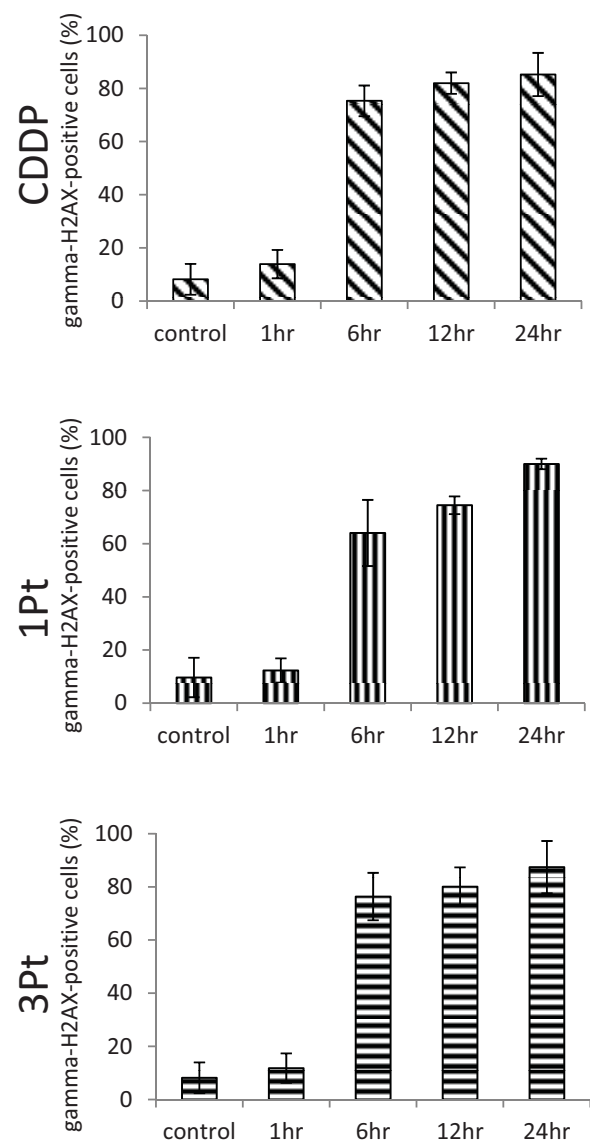

MG63
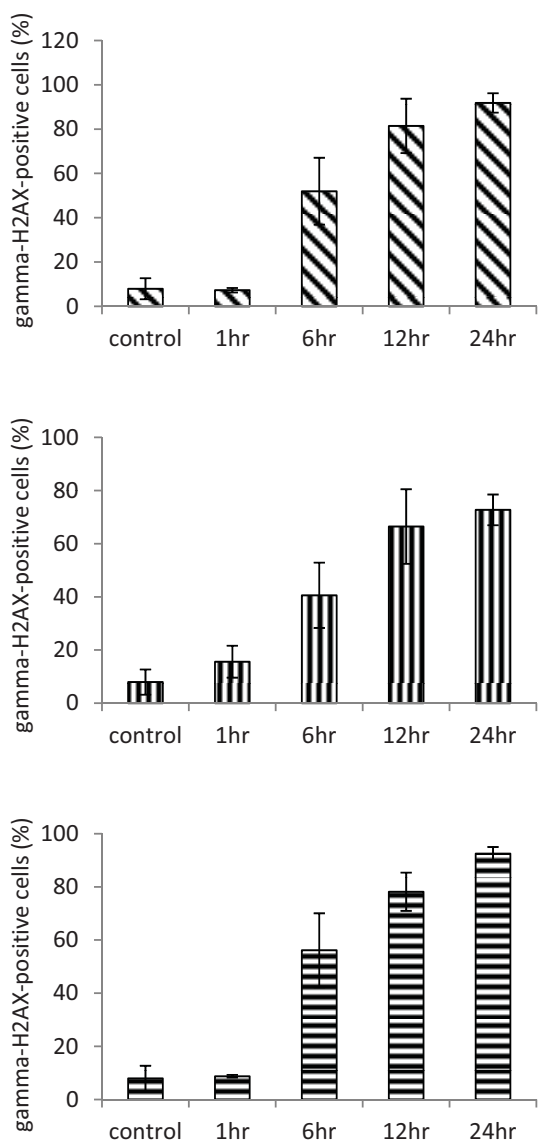

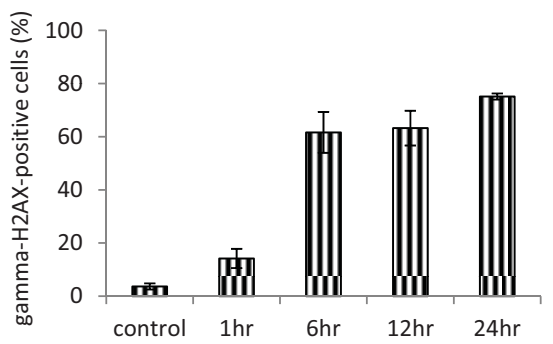

143B
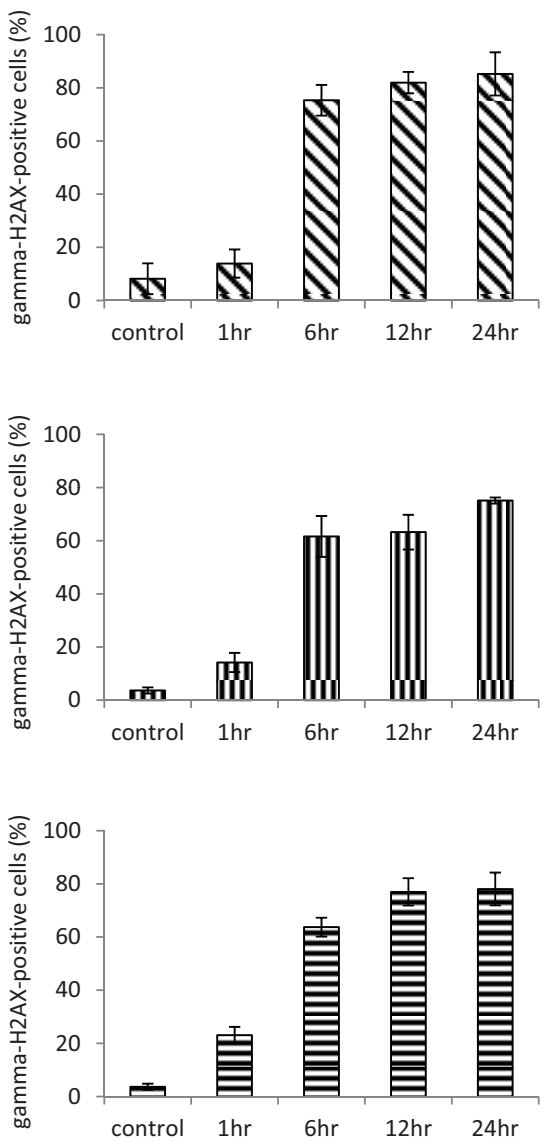

Fig. (6). A. Formation of gamma-H2AX foci induced by the platinum complexes in 143B cells. The cells were incubated with each platinum complex for $48 \mathrm{~h}$, fixed, and subjected to immunofluorescence staining for $\gamma$-H2AX. B. Formation of gamma-H2AX foci induced by the platinum complexes in LM8, MG63 and 143B cells. They were then fixed and subjected to immunofluorescence staining for gamma-H2AX and the percentage of cells containing gamma-H2AX foci was determined. Data are means \pm s.e. 


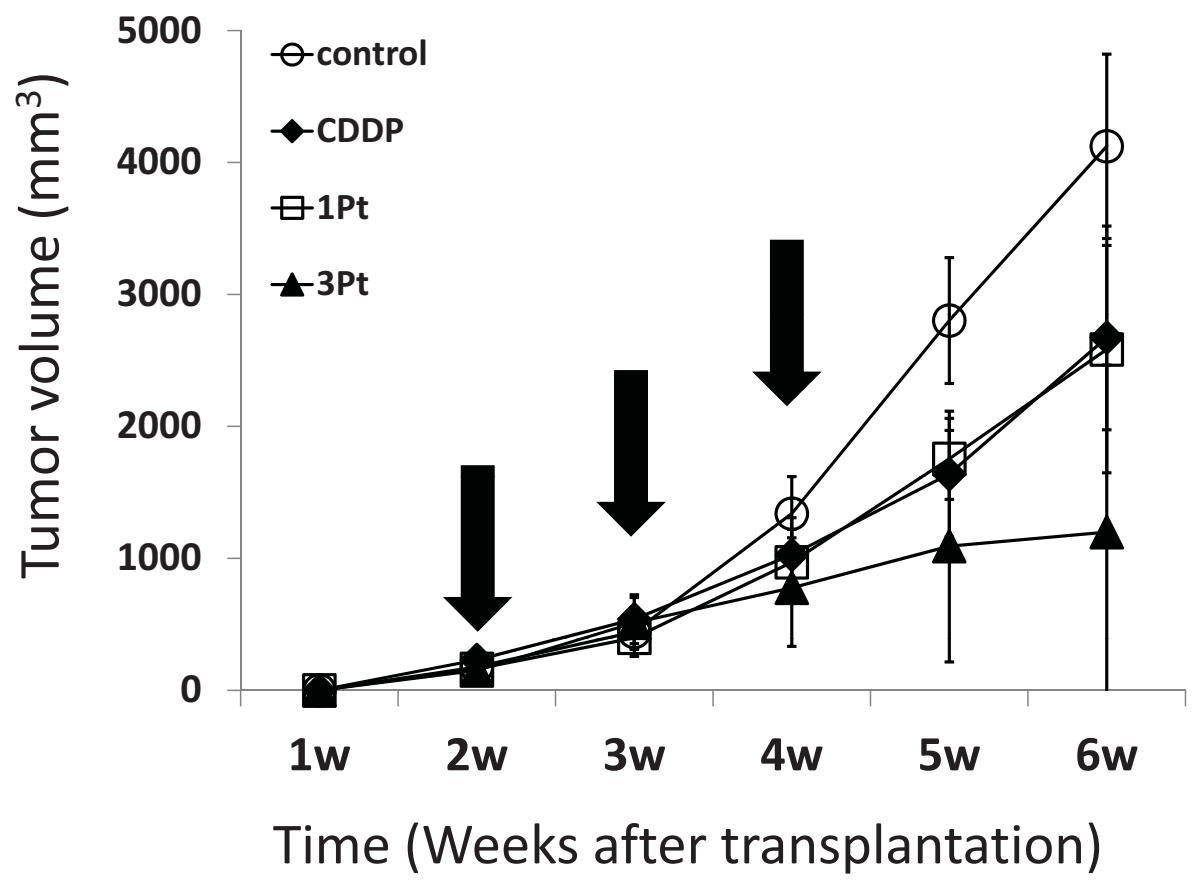

Fig. (7). In vivo antitumor effects of the platinum complexes. 143B cells were transplanted into the tibia of nude mice and allowed to form tumors, following which the mice were assigned to 1 of 4 treatment groups (control, cisplatin, 1 Pt, or 3Pt) as described in Materials and Methods section. Tumor volume was measured at the indicated time points after the onset of treatment. All data are presented as mean \pm standard deviation for 8 mice/group.

$\mathrm{H} 2 \mathrm{AX}$ phosphorylation to yield $\gamma$-H2AX, a marker of DNA doublestrand breaks. 143B, MG63, and LM8 cell exposure to $1 \mathrm{Pt}$ or $3 \mathrm{Pt}$ resulted in gradual $\gamma-\mathrm{H} 2 \mathrm{AX}$ foci accumulation, similar to the effects of cisplatin (Fig. 6A, B).

\section{Orthotopic Mouse Model}

143B cells were transplanted intratibialy in nude mice. At 6 weeks, 143B tumor treatment with $3 \mathrm{Pt}$ resulted in the largest, most significant, and most effective decrease in tumor volume compared with no treatment. 1Pt demonstrated almost the same effects as those of cisplatin. There were no animal deaths in any group (Fig. 7).

\section{DISCUSSION}

Cisplatin received clinical approval in 1978 and remains as one of the most powerful drugs for the treatment of testicular and ovarian cancer since then. Widespread clinical cisplatin use for malignant tumors has prompted a search for new platinum agents. Currently, carboplatin and oxaliplatin are widely applied clinically, although their clinical use against osteosarcoma has been limited. Direct cisplatin analogs interact with DNA-processing proteins in a similar manner as the parent drug. Differences in antitumor activities and toxicities may be mediated by differences in pharmacokinetics or reactivity rather than increased DNA function inhibition. Platinum compounds that are structurally different from cisplatin may form different platinum-DNA adduct types; however, they exhibit a spectrum of clinical activity complementary to that of the parent drug, such as the two novel Pt drugs described here.

In this study, the antitumor effects of the two novel platinum complexes were evaluated against osteosarcoma cell lines and in an orthotopic mouse model. Each complex exhibited excellent organic and aqueous solution solubility.

The results of the present study showed that both complexes demonstrated strong antitumor activity. The cytotoxic potency of 3Pt was markedly higher than that of cisplatin. The detection of apoptosis by annexin V-FITC revealed that 3Pt inhibited 143B cell proliferation by increasing the apoptotic and necrotic cell number and that the apoptotic effect of cisplatin was weak.

Some studies reported varied cytotoxicity levels depending on the Pt complex structure [22]. A recent review explained how small changes in molecular structure can cause profound differences in biological activity [23]. Traditionally, few platinum cation complexes possess antitumor effects. However, a recent study on charged trinuclear cation platinum BBR3464 revealed that charge incorporation into the linker backbone and hydrogen-bonding capacity increased DNA affinity [24]. These features contribute to different DNA binding, cellular uptake, and antitumor activities within the polynuclear platinum family. Since $3 \mathrm{Pt}$ is an unusual trinuclear anion complex, it is expected to involve specific drug-bone interactions.

Cisplatin adducts and analogs distort DNA conformation $[25,26]$, inhibit replication and transcription $[27,28]$, and induce apoptosis or necrosis [29]. In addition, cisplatin adducts are removed from DNA mainly by the nucleotide excision repair system [30]. Although changes in the association process with DNA may exist, $1 \mathrm{Pt}$ and $3 \mathrm{Pt}$ cause dose-dependent apoptosis, similar to cisplatin. $\mathrm{H} 2 \mathrm{AX}$ phosphorylation after drug administration was also found to be time-dependent.

Cisplatin efficacy against malignant tumors is limited because of resistance, either intrinsic or acquired. The mechanism underlying cisplatin resistance appears to be multifactorial because cancer cells can develop cisplatin resistance through changes in drug transport, enhanced drug detoxification systems, and changes in DNA repair mechanisms, such as increased nucleotide excision repair, interstrand crosslink repair, and mismatch repair loss $[31,32]$. Both novel platinum complexes showed efficacy against cisplatin-resistant cells. These antitumor activities against cisplatinresistant cell lines suggested the ability to overcome the multiple mechanisms underlying cisplatin resistance. $3 \mathrm{Pt}$ was designed to target bone tissue and contains germinal bisphosphonate moieties for drug delivery, even if in low concentrations. Although antitumor activity at such low bisphosphonate concentrations may be nil, $3 \mathrm{Pt}$ is expected to be delivered to bone and bone-forming tumors more 
effectively. Because 3Pt is also effective against many cancer cell lines, it may be effective against bone metastases.

Among the new protein targets, the proteasome may be a major target of 1Pt because of its strong inhibition [12].

$1 \mathrm{Pt}$ showed strong antitumor activities by inducing DNA double-strand breaks, similar to cisplatin. However, 1Pt could not coordinate DNA because no ligand-exchange reaction was observed using H1-NMR on mixing $1 \mathrm{Pt}$ and guanosine $5^{\prime}$-phosphate $\left(5^{\prime}\right.$ GMP). Then, the DNA event may occur after $1 \mathrm{Pt}$ interacts noncovalently with DNA and protein, as estimated in structurally similar Pt compounds such as Pt(56-dimethylphenanthroline)(sdach) [33-35]. Among the possible protein targets, such as kinase, telomerase, and proteasome, the proteasome may be a major target of $1 \mathrm{Pt}$ because $\mathrm{Cu}$-phenanthroline (amino acid) exhibits a coordination structure similar to that of $1 \mathrm{Pt}$ and was reported to demonstrate proteasome inhibition [36]. The proteasome inhibitory activity has not received much attention because the proteasome inhibitor enhances the transport of the drug to the nuclei and is expected to act synergistically with the drug [37]. Proteasome inhibition by covalent bonding to the boronic acid moiety of the clinical drug bortezomib is well known; however, the problem of drug resistance led to the development of a noncovalent-type inhibitor [38].

Bortezomib, a boronic acid dipeptide, was the first proteasome inhibitor approved by the U.S. Food and Drug Administration for myeloma treatment [39]. The proteasome is the primary component of the protein degradation pathway. Through the degradation of regulatory proteins, the proteasome serves as a central conduit for many cellular regulatory signals; therefore, it is an attractive therapeutic drug target. The NF-kappa B signaling pathway may be a critical target for proteasome inhibitors. This repression is released in response to cellular stresses that cause targeted proteasome-induced I-kappa B degradation to release NF-kappa B [40-44], which is rapidly translocated to the nucleus where it increases production of cytokines, including vascular endothelial growth factor, tumor necrosis factor, interleukin-1, interleukin-6, and cell adhesion molecules. NF-kappa B can also increase antiapoptotic expression of $\mathrm{Bcl}-2$ protein family members [45-48]. Dysregulation of NF-kappa B signaling is an important feature of malignancy $[49,50]$, and proteasome inhibitors produce antitumor effects by causing direct tumor cell apoptosis and exerting effects on the tumor microenvironment, such as anti-angiogenesis. Furthermore, bortezomib suppresses growth and induces apoptosis in osteosarcoma both in vitro and in vivo [51]. Therefore, proteasome inhibitors are interesting drug candidates for the treatment of osteosarcoma, considering that $1 \mathrm{Pt}$ showed strong antitumor activity in the orthotopic mouse model through probable proteasome inhibition.

\section{CONCLUSIONS}

We developed two novel platinum complexes that exhibited powerful antitumor effects against osteosarcoma cell lines and in an orthotopic mouse model. Therefore, these novel Pt complexes may represent a new class of potent antisarcoma agents. In addition enhanced chemotherapy by caffeine addition was possible. However, further in vitro studies are required to unravel the putative mechanisms underlying their actions, including DNA interactions.

\section{CONFLICT OF INTEREST}

The author(s) confirm that this article content has no conflict of interest.

\section{ACKNOWLEDGEMENTS}

This research was supported by The Mitani Foundation for Research and Development, and Basic Science Research Program through the National Research Foundation of Japan funded by the
Ministry of Education, Culture, Sports, Science, and Technology of Japan.

\section{REFERENCES}

[1] Yamamoto, N.; Tsuchiya, H. Chemotherapy for osteosarcoma where does it come from? What is it? Where is it going? Exp. Opin. Pharmacother., 2013, 14(16), 2183-2193.

[2] Shen, D.W.; Pouliot, L.M.; Hall, M.D.; Gottesman, M.M. Cisplatin resistance: A cellular self-defense mechanism resulting from multiple epigenetic and genetic changes. Pharmacol. Rev., 2012, 64(3), 706-721.

[3] Jaffe, N. Osteosarcoma: Review of the past, impact on the future. The American experience. Cancer Treat. Res., 2009, 152, 239-262.

[4] Bode, A.M.; Dong, Z. The enigmatic effects of caffeine in cell cycle and cancer. Cancer Lett., 2007, 247, 26-39.

[5] Tsuchiya, H.; Tomita, K.; Mori, Y.; Asada, N.; Yamamoto, N. Marginal excision for osteosarcoma with caffeine assisted chemotherapy. Clin. Orthop., 1999, 358, 27-35.

[6] Hayashi, K.; Tsuchiya, H.; Yamamoto, N.; Shirai, T.; Yamauchi, K.; Takeuchi, A.; Kawahara, M.; Miyamoto, K.; Tomita, K. Impact of serum caffeine monitoring on adverse effects and chemotherapeutic responses to caffeine-potentiated chemotherapy for osteosarcoma. J. Orthop. Sci., 2009, 14, 253-258.

[7] Kimura, H.; Tsuchiya, H.; Shirai, T.; Nishida, H.; Hayashi, K.; Takeuchi, A.; Ohnari, I.; Tomita, K. Caffeine-potentiated chemotherapy for metastatic osteosarcoma. J. Orthop. Sci., 2009, 14, 556-565.

[8] Bacci, G.; Briccoli, A.; Ferrari, S.; Longhi, A.; Mercuri, M.; Capanna, R.; Donati, D.; Lari, S.; Forni, C.; DePaolis, M. Neoadjuvant chemotherapy for osteosarcoma of the extremity: long-term results of the Rizzoli's $4^{\text {th }}$ protocol. Eur. J. Cancer., 2001, 37(16), 2030-2039.

[9] Iwamoto, Y.; Tanaka, K.; Isu, K.; Kawai, A.; Tatezaki, S.; Ishii, T.; Kushida, K.; Beppu, Y.; Usui, M.; Tateishi, A.; Furuse, K.; Minamizaki, T.; Kawaguchi, N.; Yamawaki, S. Multiinstitutional phase II study of neoadjuvant chemotherapy for osteosarcoma (NECO study) in Japan: NECO-93J and NECO-95J. J. Orthop. Sci., 2009, 14(4), 397-404.

[10] Ferrari, S.; Ruggieri, P.; Cefalo, G.; Tamburini, A.; Capanna, R.; Fagioli, F.; Comandone, A.; Bertulli, R.; Bisogno, G.; Palmerini, E.; Alberghini, M.; Parafioriti, A.; Linari, A.; Picci, P.; Bacci, G. Neoadjuvant chemotherapy with methotrexate, cisplatin, and doxorubicin with or without ifosfamide in nonmetastatic osteosarcoma of the extremity: an Italian sarcoma group trial ISG/OS-1. J. Clin. Oncol., 2012, 30, 2112-2118.

[11] Durnali, A.; Alkis, N.; Cangur, S.; Yukruk, F.A.; Inal, A.; Tokluoglu, S.; Seker, M.M.; Bal, O.; Akman, T.; Inanc, M.; Isikdogan, A.; Demirci, A.; Helvaci, K.; Oksuzoglu, B. Prognostic factors for teenage and adult patients with high-grade osteosarcoma: An analysis of 240 patients. Med. Oncol., 2013, 624 .

[12] A, Odani. Metal complexes and anticancer agents comprising same as active ingredient, Patent WO 2011125911 A1. 2011-10-13

[13] McClung, M.; Harris, ST.; Miller, P.D.; Bauer, D.C.; Davison, K.S.; Dian, L.; Hanley, D.A.; Kendler, D.L.; Yuen, C.K. Lewiecki EM. Bisphosphonate therapy for osteoporosis: Benefits, risks, and drug holiday. Am. J. Med., 2013, 126(1), 13-20.

[14] Holen, I.; Coleman, R.E. Bisphosphonates as treatment of bone metastases. Curr. Pharm, Des., 2010, 16(11), 1262-1271.

[15] Jobke, B.; Milovanovic, P.; Amling, M.; Busse, B. Bisphosphonateosteoclasts: Changes in osteoclast morphology and function induced by antiresorptive nitrogen-containing bisphosphonate treatment in osteoporosis patients. Bone, 2014, 59, 37-43.

[16] Park, S.; Lippard, S.J. Binding Interaction of HMGB4 with Cisplatin-Modified DNA. Biochemistry, 2012, 51(34), 6728-6737.

[17] Sunwoo, J.B.; Chen, Z.; Dong, G.; Yeh, N.; Crowl Bancroft, C.; Sausville, E.; Adams, J.; Elliott, P.; Van Waes, C. Novel proteasome inhibitor PS-341 inhibits activation of nuclear factor$\kappa \mathrm{B}$, cell survival, tumor growth, and angiogenesis in squamous cell carcinoma. Clin. Cancer Res., 2001, 7(5), 1419-1428.

[18] Westermann, B. Molecular machinery of mitochondrial fusion and fission. J. Biol. Chem., 2008, 283(20), 13501-13505.

[19] Vermes, I.; Haanen, C.; Steffens-Nakken, H.; Reutelingsperger, C. A novel assay for apoptosis. Flow cytometric detection of phosphatidylserine expression on early apoptotic cells using 
fluorescein labelled Annexin V. J. Immunol Methods., 1995, 184(1), 39-51.

[20] De Schepper, S.; Bruwiere, H.; Verhulst, T.; Steller, U.; Andries, L.; Wouters, W.; Janicot, M.; Arts, J.; Van Heusden, J. Inhibition of histone deacetylases by chlamydocin induces apoptosis and proteasomemediated degradation of survivin. J. Pharmacol. Exp. Ther., 2003, 304(2), 881-888.

[21] Diggle, C.P.; Bentley, J.; Knowles, M.A.; Kiltie, A.E. Inhibition of double-strand break non-homologous end-joining by cisplatin adducts in human cell extracts. Nucleic Acids Res., 2005, 33(8), 2531-2539.

[22] Hambley, TW. The influence of structure on the activity and toxicity of $\mathrm{Pt}$ anti-cancer drugs. Coord. Chem. Rev., 1997, 166, 181-223.

[23] Zhu, G.; Song, L.; Lippard, SJ. Visualizing inhibition of nucleosome mobility and transcription by cisplatin-DNA interstrand crosslinks in live mammalian cells. Cancer Res., 2013, 73(14), 4451-4460.

[24] Banerjee, T.; Dubey, P.; Mukhopadhyay, R. DNA compaction by mononuclear platinum cancer drug cisplatin and the trisplatinum anticancer agent BBR3464: Differences and similarities. Biochimie, 2012, 94(2), 494-502.

[25] Brabec, V. DNA modifications by antitumor platinum and ruthenium compounds: Their recognition and repair. Prog. Nucleic Acid Res. Mol. Biol., 2002, 71, 1-68.

[26] Cohen, S.M.; Lippard, S.J. Cisplatin: From DNA damage to cancer chemotherapy. Prog. Nucleic Acid Res. Mol. Biol., 2001, 67, 93130 .

[27] Jung, Y.; Lippard, S.J. Direct cellular responses to platinuminduced DNA damage. Chem. Rev., 2007, 107(5), 1387-1407.

[28] Wang, D.; Lippard, S.J. Cellular processing of platinum anticancer drugs. Nat. Rev. Drug Discov., 2005, 4(4), 307-320.

[29] Fuertes, M.A.; Castilla, J.; Alonso, C.; Perez, J.M. Cisplatin biochemical mechanism of action: From cytotoxicity to induction of cell death through interconnections between apoptotic and necrotic pathways. Curr. Med. Chem., 2003, 10(3), 257-266.

[30] Kartalou, M.; Essigmann, J.M. Recognition of cisplatin adducts by cellular proteins. Mutat. Res., 2001, 478(1-2), 1-21.

[31] Kartalou, M.; Essigmann, J.M. Mechanisms of resistance to cisplatin. Mutat. Res., 2001, 478(1-2), 23-43.

[32] Rabik, C.A.; Dolan, M.E. Molecular mechanisms of resistance and toxicity associated with platinating agent. Cancer Treat. Rev., 2007, 33(1), 9-23.

[33] Krause-Heuer, A.M.; Grunert, R.; Kuhne, S.; Buczkowska, M.; Wheate, N.J.; Le Pevelen, D.D.; Boag, L.R.; Fisher, D.M.; Kasparkova, J.; Malina, J.; Bednarski, P.J.; Brabec, V.; AldrichWright, J.R. Studies of the mechanism of action of platinum(II) complexes with potent cytotoxicity in human cancer cells. J. Med. Chem., 2009, 52, 5474-5484.

[34] Davis, K.J.; Carrall, J.A.; Lai, B.; Aldrich-Wright, J.R.; Ralph, S.F.; Dillon, C.T. Does cytotoxicity of metallointercalators correlate with cellular uptake or DNA affinity? Dalton Trans., 2012, 41, 9417-9426.

[35] Garbutcheon-Singh, K.B.; Myers, S.; Harper, B.W.; Ng, N.S.; Dong, Q.; Xie, C.; Aldrich-Wright, J.R. The effects of 56MESS on mitochondrial and cytoskeletal proteins and the cell cycle in MDCK cells. Metallomics, 2013, 5, 1061-1067.

[36] Ng, C.H.; Kong, S.M.; Tiong, Y.L.; Maah, M.J.; Sukram, N.; Ahmad, M.; Khoo, A.S. Selective anticancer copper(II)-mixed ligand complexes: Targeting of ROS and proteasomes. Metallomics, 2014, 6, 892-906.

[37] Gatti, L.; Zuco, V.; Zaffaroni, N.; Perego, P. Drug combinations with proteasome inhibitors in antitumor therapy. Curr. Pharm. Des., 2013, 19 (22), 4094-4114.

[38] Kazi, A.; Ozcan, S.; Tecleab, A.; Sun, Y.; Lawrence, H.R.; Sebti, S.M. Discovery of PI-1840, a novel noncovalent and rapidly reversible proteasome inhibitor with anti-tumor activity. J. Biol. Chem., 2014, 289(17), 11906-11915.

[39] Chen, D.; Frezza, M.; Schmitt, S.; Kanwar, J.; Dou, Q.P. Bortezomib as the first proteasome inhibitor anticancer drug: Current status and future perspectives. Curr. Cancer Drug Targets. 2011, 11(3), 239-253.

[40] Alkalay, I.; Yaron, A.; Hatzubai, A.; Orian, A.; Ciechanover, A.; Ben-Neriah, Y. Stimulation-dependent I $\mathrm{KB} \alpha$ phosphorylation marks the NF- $\kappa \mathrm{B}$ inhibitor for degradation via the ubiquitinproteasome pathway. Proc. Natl. Acad. Sci. USA, 1995, 92(23), 10599-10603.

[41] Baldi, L.; Brown, K.; Franzoso, G.; Siebenlist, U. Critical role for lysines 21 and 22 in signal-induced, ubiquitin-mediated proteolysis

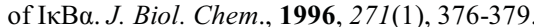

[42] Chen, Z.; Hagler, J.; Palombella, VJ.; Melandri, F.; Scherer, D.; Ballard, D.; Maniatis, T. Signal-induced site-specific phosphorylation targets $\mathrm{I} \kappa \mathrm{B} \alpha$ to the ubiquitin-proteasome pathway. Genes Dev., 1995, $9(13), 1586-1597$.

[43] Lin, YC.; Brown, K.; Siebenlist, U. Activation of NF- $\kappa$ B requires proteolysis of the inhibitor I $\kappa \mathrm{B}-\alpha$ : Signal-induced phosphorylation

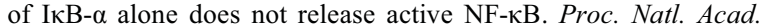
Sci. USA, 1995, 92(2), 552-556.

[44] Roff, M.; Thompson, J.; Rodriguez, M.S.; Jacque, J.M.; Baleux, F.; Arenzana-Seisdedos, F.; Hay, R.T. Role of $\mathrm{I} \kappa \mathrm{B} \alpha$ ubiquitination in signal-induced activation of NF- $\kappa \mathrm{B}$ in vivo. J. Biol. Chem., 1996, 271(13), 7844-7850

[45] Chen, C.; Edelstein, L.C.; Gelinas, C. The Rel/NF- $\kappa$ B family directly activates expression of the apoptosis inhibitor Bcl-xL. Mol. Cell Biol., 2000, 20(8), 2687-2695.

[46] Wang, CY.; Mayo, M.W.; Korneluk, R.G.; Goeddel, D.V.; Baldwin, A.S. Jr. NF-кB antiapoptosis: Induction of TRAF1 and TRAF2 and c-IAP1 and c-IAP2 to suppress caspase- 8 activation. Science, 1998, 281(5383), 1680-1683.

[47] Wang, C.Y.; Guttridge, D.C.; Mayo, M.W.; Baldwin, A.S. Jr. NF$\kappa \mathrm{B}$ induces expression of the Bcl-2 homologue A1/Bfl-1 to preferentially suppress chemotherapy-induced apoptosis. Mol. Cell Biol., 1999, 19(9), 5923-5929.

[48] Zong, W.X.; Edelstein, L.C.; Chen, C.; Bash, J.; Gélinas, C. The prosurvival $\mathrm{Bcl}-2$ homolog $\mathrm{Bfl}-1 / \mathrm{A} 1$ is a direct transcriptional target of NF- $\mathrm{BB}$ that blocks $\mathrm{TNF} \alpha$-induced apoptosis. Genes Dev., 1999, 13(4), 382-387.

[49] Kordes, U.; Krappmann, D.; Heissmeyer, V.; Ludwig, W.D.; Scheidereit, C. Transcription factor NF- $\kappa \mathrm{B}$ is constitutively activated in acute lymphoblastic leukemia cells. Leukemia, 2000, 14(3), 399402 .

[50] Tricot, G. New insights into role of microenvironment in multiple myeloma. Lancet, 2000, 355(9200), 248-250.

[51] Shapovalov, Y.; Benavidez, D.; Zuch, D.; Eliseev, R.A. Proteasome inhibition with bortezomib suppresses growth and induces apoptosis in osteosarcoma. Int. J. Cancer, 2010, 127(1), 67-76. 